\title{
Analisis Kemampuan Berpikir Kritis Siswa pada Aspek Advanced Clarification dan Inference Konsep Sistem Pencernaan di Kelas XI MIPA SMA Negeri 2
} Tanjungpinang

\author{
Oktaviani Dwi Putri $^{1^{*}}$, Nevrita ${ }^{2}$, Nur Eka Kusuma Hindrasti ${ }^{3}$ \\ ${ }^{1,2,3)}$ Program Studi Pendidikan Biologi, Fakultas Keguruan dan Ilmu Pendidikan, Universitas Maritim Raja Ali Haji, \\ Tanjungpinang, Indonesia
}

Pengiriman: 22 Maret 2019; Diterima: 2 Oktober 2019; Publikasi: Nopember 2019

\begin{abstract}
The purpose of this study is to describe students' critical thinking skills in the aspects of advanced clarification and inference of the XI MIPA class of SMA Negeri 2 Tanjungpinang. The population of this study were all students of class XI MIPA of SMA Negeri 2 Tanjungpinang consisting of 7 classes with a total of 259 students. The sample in this study amounted to 146 taken with cluster random sampling techniques. Data collection techniques through tests in the form of questions were developed using indicators of critical thinking skills. Test instruments are used to determine students' critical thinking skills in the aspects of advanced clarification and inference. Based on data analysis, it is known that the average percentage in the advanced clarification aspect is $63 \%$ with a category and $62 \%$ inference. So the conclusion in this study that the ability to think critically in the advanced clarification and inference aspects of class XI MIPA students of SMA Negeri 2 Tanjungpinang in the category is quite critical.
\end{abstract}

Keywords: Digestive System, Critical Thinking Ability, Advanced Clarification.

\begin{abstract}
ABSTRAK: Tujuan penelitian ini untuk mendeskripsikan kemampuan berpikir kritis siswa pada aspek advanced clarification dan inference kelas XI MIPA SMA Negeri 2 Tanjungpinang. Populasi penelitian ini adalah seluruh siswa kelas XI MIPA SMA Negeri 2 Tanjungpinang yang terdiri dari 7 kelas dengan total 259 siswa. Sampel dalam penelitian ini berjumlah 146 yang diambil dengan teknik cluster random sampling.Teknik pengumpulan data melalui tes berupa soal yang dikembangkan menggunakan indicator kemampuan berpikir kritis. Intrumen tes digunakan untuk mengetahui kemampuan berpikir kritis siswa pada aspek advanced clarification dan inference. Berdasarkan analisis data maka diketahui rata-rata persentase pada aspek advanced clarificationadalah 63\% dengan kategori dan inference 62\%. Maka kesimpulan dalam penelitian ini bahwa kemampuan berpikir kritis pada aspek advanced clarification dan inference siswa kelas XI MIPA SMA Negeri 2 Tanjungpinang pada kategori cukup kritis.
\end{abstract}

Kata Kunci: Sistem Pencernaan, Kemampuan Berpikir kritis, Advanced Clarification.

*Penulis Korespondensi:

Alamat surel: oktadwiputri97@gmail.com 


\section{PENDAHULUAN}

Pendidikan adalah proses pengubahan sikap dan tingkah laku individu atau kelompok dalam upaya mendewasakan manusia melalui pelatihan dan pengajaran dengan berbagai metode tertentu sehingga memperoleh pengetahuan, pemahaman dan cara bertingkah laku sesuai dengan kebutuhan (Syah, 2006: 10). Sejalan dengan pendapat Jufri (2013: 33)bahwa pendidikan merupakan sebuah upaya yang dilakukan untuk membangun karakter yang baik dan melatih mental kemandirin. Berdasarkan beberapa pendapat tersebut maka pedidikan sangat dibutuhkan guna menjalani kehidupan di lingkungan masyarakat dengan baik.

Pembelajaran merupakan suatu sistem tersistematis yang didalamnya meliputi pengajaran, pelatihan dan pengembangan diri sebagai upaya meningkatkan pengetahuan dan pemahaman seseorang (Rusman, 2012: 93). Adapun beberapa komponen pembelajaran yang saling berhubungan satu dengan lainnya meliputi: tujuan, materi, metode, dan evaluasi yang masing-masing komponen tersebut harus diperhatikan oleh guru dalam memilih dan menentukan media, metode, strategi, dan pendekatan apa yang digunakan dalam pembelajaran.

Berdasarkan permendikbud tahun 2016 bahwa siswa diharapkan memiliki sikap kritis agar mampu memecahkan masalah secara tepat. Menurut Ennis (2015: 1) bahwa kemampuan berpikir kritis adalah kemampuan seseorang untuk memiliki alasan yang jelas dengan apa yang diyakini dan dilakukan. Berdasarkan pernyataan tersebut dapat disadari bahwa berpikir kritis merupakan suatu kegiatan reflektif yang pada akhirnya menuntun pada sebuah keputusan yang nyata. Terdapat lima aspek indikator berpikir kritis menurut Ennis yaitu klarifikasi dasar (basic clarification),dasar pengambilan keputusan (bases for dicision),kesimpulan (inference),klarifikasi lanjutan(advanced clarification), dan mengatur strategi dan taktik(strategies and tactics).

Menyadari pentingnya proses pengambilan sebuah keputusan yang diperoleh berdasarkan cara berpikir seseorang, maka dalam penelitian ini akan membahas terkait kemampuan berpikir kritis siswa pada aspek inferencedan advanced clarification. Aspek inference merupakan kemampuan siswa dalam mengidentifikasi pokok permasalahan kemudian membentuk dengan menggunakan unsur yang dibutuhkan untuk mempertimbangkan dalam upaya menarik kesimpulan terbaik (Pritananda dkk, 2015: 2). Sedangakan aspek Advanced clarification merupakan sebuah proses untuk mendapatkan pengetahuan yang lebih detail terkait suatu pokok permasalahan untuk sebagai usaha untuk lebih meyakinkan diri.

Untuk mengetahui kemampuan berpikir siswa maka dalam penelitian ini peneliti memberikan soal yang memerlukan pemikiran kritis yaitu mengerjakan latihan soal kritis yang dikembangkan berdasarkan indikator kemampuan berpikir kritis agar mampu mendorong pemikiran kritis siswa. Berdasarkan paparan tersebut, peneliti akan menganalisis kemampuan berpikir kritis siswa pada aspek advanced clarification dan inference.

\section{METODE PENELITIAN}

Penelitian ini bertujuan untuk mengetahui kemampuan berpikir kritis siswa pada aspek 
inferencedan advanced clarification yang dilaksanakan di kelas XI MIPA SMA Negeri 2 Tanjungpinang. Populasi dalam penelitian ini seluruh siswa kelas XI MIPA SMA Negeri 2 Tanjungpinang dengan total 259 siswa yang terbentuk dalam tujuh kelas. Sedangkan sampel pada penelitian ini sebanyak 146 orang yang diambil dengan teknikcluster random sampling. Penelitian ini menggunakan pendekatan kuantitatif dengan metode deskriptif untuk menggambarkan kondisi faktual kemampuan berpikir kritis siswa.Teknik pengumpulan data dalam penelitian ini yaitu soal tes yang dikembangkan dari indikator berpikir kritis.

\section{HASIL DAN PEMBAHASAN}

Berikut disajikan data mengenai skor ratarata soal tes kemampuan berpikir kritis siswa pada aspek advanced clarification dan inference.

Hasil Tes Kemampuan Berpikir Kritis Siswa

\begin{tabular}{|c|c|c|c|}
\hline $\begin{array}{l}\text { Aspek Kemampuan } \\
\text { Berpikir Kritis }\end{array}$ & $\begin{array}{l}\text { No } \\
\text { Soal }\end{array}$ & $\begin{array}{l}\text { Rata- } \\
\text { Rata } \\
\text { Skor } \\
\text { Siswa }\end{array}$ & $\begin{array}{l}\text { Persentas } \\
\text { e } \\
\text { Berdasar } \\
\text { kan } \\
\text { Aspek } \\
\text { Kemamp } \\
\text { uan } \\
\text { Berpikir } \\
\text { Kritis }\end{array}$ \\
\hline Inference(Kesimpulan) & $\begin{array}{l}6 \\
7\end{array}$ & $\begin{array}{l}0,68 \\
0,58\end{array}$ & $63 \%$ \\
\hline $\begin{array}{l}\text { Advanced Clarification } \\
\text { (Klarifikasi Lanjutan) }\end{array}$ & $\begin{array}{l}8 \\
9\end{array}$ & $\begin{array}{l}0,55 \\
0,69\end{array}$ & $62 \%$ \\
\hline
\end{tabular}

Gambar 1. Persentase Skor Siswa Berdasarkan Aspek

Berdasarkan Tabel 1. Bahwa skor siswa pada aspek inference memperoleh skor persentase 63\% dengan kategori cukup kritis dan aspek advanced clarification memperoleh skor persentase $62 \%$ juga dengan kategori cukup kritis. Pada aspek inference terdapat dua soal yang dikembangkan dengan mengacu pada indikator kemampuan berpikir kritis siswa. Adapun indikator kemampuan berpikir kritis pada aspek inference antara lain mempertanyakan fakta, membuat altrnatif dan menarik kesimpulan.

Dalam aspek inference siswa diharapkan dapat mengeneralisasikan kondisi umum dari berbagai perspektif yang berbeda, sehingga siswa mampu menilai dan mempertimbangkan setiap kesimpulan yang ia buat, baik kesimpulan deduktif maupun kesimpulan induktif. Hal ini sejalan dengan pendapat Rohati, (2014:50) seorang yang kritis berarti dapat mengintegrasi atau mensintesis hasil atau pandangan yang diperoleh selain itu juga dapat menyusun dan memeriksa ulang (recheck) guna kehati-hatian secara utuh segala unsur-unsur atau hasil yang tampak pada pandangan atau kesimpulan dengan berbagai pengetahuan yang telah diketahui.

\section{Berdasarkan skor persentase yang} diperoleh yaitu $63 \%$ dengan kategori cukup kritis maka dapat dikatakan bahwa siswa sudah cukup baik dalam menggunakan berbagai informasi yang dapat membantu dalam penyelesaian masalah sehingga siswa dapat membuat alteratif terbaik yang dapat digunakan sebagai solusi. Dalam hal ini siswa mampu mengeneralisasikan permasalahan dari berbagai perspektif yang berbeda. Siswa juga sudah terbiasa untuk melakukan proses pengecekan kembali jawaban yang ia berikan untuk sebagai upaya meminimalisir adanya kesalahan.

Selanjutnya pada aspek advanced clarification yang artinya klarifikasi lanjutan yang dapat digunakan sebagai proses verivikasi 
simpulan yang diambil agar dapat memperoleh keputusan akhir yang terbaik. Selain itu, klarifikasi lanjutan adalah proses membuat suatu definisi sebagai upaya mengklarifikasi dengan berbagai argument. Menurut Muswita (2016: 15) menjelaskan bahwa argumen harus selalu dilandasi dengan data pendukung agar suatu argumen tersebut dapat diterima orang lain. Oleh sebab itu, Dalam aspek advanced clarification siswa diharapkan untuk dapat mendefinisikan bentuk dan dapat mempertimbangkan istilah definisi sekaligus memprediksi hal-hal yang mungkin berkaitan dengan pokok permasalahan. Berdasarkan persentase skor yang diperoleh yaitu $62 \%$ maka dikategorikan pada kategori cukup kritis. Dalam hal ini siswa sudah cukup mampu mendefinisikan bentuk dan mempertimbangkan istilah serta sudah terbiasa memprediksi hal-hal terkait pokok permasalahan.

\section{KESIMPULAN DAN SARAN}

\section{Kesimpulan}

Berdasarkan hasil penelitian dapat disimpulkan bahwa kemampuan berpikir kritis siswa pada aspek inference dan aspek advanced clarification pada kategori cukup kritis yaitu dengan nilai persentase $63 \%$ pada aspek inference dan $62 \%$ pada aspek advanced clarification.

\section{Saran}

Penelitian ini terbatas pada upaya mengetahui kategori kemampuan berpikir kritis siswa pada aspek inference dan advanced clarification. Bagi peneliti selanjutnya diarapkan untuk dapat mengembangkan soal yang dapat mengukur kemampuan berpikir kritis siswa ataupun melakukan penelitian terkait metode ataupun model pembelajaran yang dapat meningkatkan kemampuan berpikir kritis siswa.

\section{DAFTAR PUSTAKA}

Ennis, R.H. 2015. Critical Thinking Assessment.Taylor and Francis. Vol. 32 (3) hal.179-186

Jufri, W. 2013. Belajar dan Pembelajaran SAINS. Bandung: Pustaka Rineka Cipta.

Muswita, Budiarti, R.S, Sulistiani, E. 2016. Analisis Kemampuan Berpikir Kritis Siswa Lintas Minat Pada Pembelajaran Biologi Kelas X IIS SMA Negeri 11 Kota Jambi. Jurnal BIODIK. Vol 2 (1). Hal 1319

Rusman. 2012. Belajar dan Pembelajaran Berbasis Komputer Mengembangkan Profesionalitas Guru Abad 21. Bandung: Alfabeta

Rohati. Proses Berpikir Kritis Siswa SMP Tipe Influence Dalam Memecahkan Masalah Matematika. Jurnal Edumatica FKIP Universitas Jambi. Vol. 04 (01)

Syah, Muhibbin. 2006. Psikologi Pendidikan. Bandung. PT. Remaja Rosdakarya

Pritananda, dkk. 2015. Kemampuan Berpikir Kritis Siswa pada Aspek Inference dalam Menyelesaikan Soal Cerita Teorema Pythagoras. Matematika FKIP Untan Pontianak. Hal. 1- 8 